\title{
PRODUCTIVITY AND NUTRIENT BALANCE OF LENTIL- MUNGBEAN -T. AUS - T. AMAN RICE CROPPING PATTERN IN HIGH BARIND TRACT
}

\author{
M. S. Hossain ${ }^{1 *}$, S. M. M. Alam ${ }^{1}$, M. Y. Abida ${ }^{1}$, M. K. Hasan' ${ }^{2}$ and A. S. M. M. R. Khan ${ }^{2}$ \\ ${ }^{1}$ On-Farm Research Division, BARI, Barind, Rajshahi \\ ${ }^{2}$ On-Farm Research Division, BARI, Gazipur, Bangladesh \\ *Corresponding author, E-mail:shossain72@yahoo.com
}

(Received: 1 January 2018, Accepted: 11 April 2018)

Keywords: Four crops pattern, system productivity, MBCR and nutrient balance

\begin{abstract}
A field experiment viz. was conducted at farmers' field of Field Service Research Division site, Kadamshahar, Godagari, Rajshahi under High Barind Tracts to evaluate the the effect of the intensive cropping on system productivity and economic returns as well as nutrient balance and changes in soil fertility of four crop-based cropping pattern Lentil -Mungbean -T.Aus -T.Aman during 2015-2016 and 2016-2017. The Lentil - Mungbean-T.Aus -T. Aman rice cropping pattern was considered as improved pattern (IP) and compared with the farmers' practice (FP) of Boro - Fallow -T.Aman rice cropping pattern. The Lentil-Mungbean- T.Aus -T.Aman cropping pattern was involved with higher cultivation cost but having the higher rice equivalent yield (REY $15.01 \mathrm{t} \mathrm{ha}^{-1}$ ), gross return (Tk. $265500 \mathrm{ha}^{-1}$ ), gross margin (Tk. $134750 \mathrm{ha}^{-1}$ ) and marginal benefit-cost ratio (1.38). This cropping pattern gave $46 \%$ higher REY compared to the existing Boro-Fallow-T. Aman rice pattern. The four crop pattern took 345 days in a year for its cycle completion. Incorporation of legume residues into the soil in IP increased soil organic matter, total $\mathrm{N}$, available $\mathrm{P}$ and $\mathrm{Zn}$ contents, as observed after two crop cycles. The IP increased N, P and K uptake by the crops in the sequence. The apparent balance, i.e. difference between inputs and outputs for $\mathrm{N}$ and $\mathrm{K}$ was negative. The apparent $\mathrm{P}$ balance was positive in IP while it was negative in FP. Therefore, it is concluded that the practicing Lentil- Mungbean-T.Aus-T.Aman rice cropping pattern is a productive and profitable system of production technology in the high Barind Tract.
\end{abstract}

\section{Introduction}

Bangladesh is the densely populated (1237 per sq. km.) country of the world with an increasing population rate of $1.05 \%$ per year (World meters, 2017). At present total cultivable land is 7.95 million hectare (BBS, 2016) which is decreasing at the rate of about $0.44 \%$ per year. There is a very little scope for increasing cultivable land but there are some rooms for increasing cropping intensity from the present 194 to $400 \%$ by incorporating short duration crops like lentil, mungbean and aus rice in the rice based cropping pattern. Sustainable crop production in Bangladesh through improvement of cropping pattern in rice based cropping system is regarded as increasingly important in national issues such as food security, poverty alleviation and creation of job opportunity. The main challenge of the new millennium is to increase per unit yield by at least $50 \%$ through manipulating the limited land resource. In case of production agronomy, targeting high yield with high cropping intensity and productivity is the most logical way to raise the total production. In order to produce more food within a limited area, most important options are to increase the cropping intensity producing three or more crops over the 
same piece of land in a year and ii) to increase the production efficiency of the individual crop by using optimum management practices.

Soil nutrients (N, P, K, S, Zn, B etc.) play an important role for regulating the supply of nutrients to plant (Konrad et al., 2001). High yielding varieties of crops uptake higher amount of nutrients from soils resulting in depletion of soil organic matter and deterioration of soil fertility that poses a great threat to sustainable crop production. Moreover, continuous cropping without adequate replacement of removed nutrients and nutrient loss through erosion, leaching, and gaseous emission is causing a depletion soil fertility as well as soil organic matter ( $\mathrm{Yu}$, et al., 2014 and Tirol-Padre et al., 2007). The areas of pulse in Rabi season are decreased because of increasing cultivation of irrigated Boro rice. Recently with the development of short duration rice and pulse crops an opportunity has been created to accommodate four crops in the same piece of land in a year.

High Barind Tract is recognized as drought prone area in Bangladesh and its soil fertility is low compared to other parts of the country. So, lentil and mungbean were chosen as component crop in four crop based cropping pattern by replacing Boro rice. Besides, lentil and mungbean are the low water consuming crops. T. Aus rice can be cultivated with minimum irrigation water as monsoon remains active during its growing period. The present study was thus undertaken to evaluate the economic feasibility of growing four crops in respect of productivity and nutrient balance in a year in the same piece of land by incorporating lentil, mungbean and T. Aus rice in the present cropping pattern Boro-Fallow-T. Aman rice.

\section{Materials and Methods}

The four crop based cropping pattern (Lentil-Mungbean-T.Aus-T.Aman) was tested in the farmer's field of FSRD site, Kadamshahar, Godagari, Rajshahi during 2015-16 and 2016-17. The soil of the experimental plots belongs to Amnura series under AEZ 26. The soil of the experimental site was collected from two soil depth $(0-15 \mathrm{~cm}$ and $15-30 \mathrm{~cm})$ and analyzed and chemical properties of initial and final soil (after two crop cycle) were presented in Table 1 and Table 2. The experiment covered one hectare of land. Land was selected based on the discussion with local farmers, DAE personnel and available secondary information. The improved pattern (IP) Lentil-Mungbean-T.Aus-T.Aman (IP) was compared with farmers' practice (FP) BoroFallow-T.Aman. The experiment was designed with two cropping patterns as a treatment and laid out in a randomized complete block design with six dispersed replications. In IP, lentil var. BARI Masur-6, mungbean var. BARI Mung-6, rice var. BRRI dhan 48 and BRRI dhan57 were used for lentil, mungbean, T. Aus and T. Aman rice, respectively. In FP, rice var. BRRI dhan 28 was used for Boro rice and Swarna for T. Aman rice in both the years. In Barind area, farmers normally used drought tolerant T. aman var. Swarna. The trial was started with mungbean crop and completed two crop cycles in two consecutive years. The rates of the fertilizers for different crops were calculated using soil test value based (STB) on high yield goal as per FRG (BARC, 2012). The details of the varieties used and cultural operations adopted in different crops are given in Table 3. For mungbean and lentil, all the inorganic fertilizers were applied at the time of final land preparation. In case of T.Aus and T. Aman rice, all the fertilizers except urea were applied as basal. Urea was applied as top dressing in three equal splits at 10, 25 and 40 days after transplanting. All the crops were harvested at maturity from five spots with an area of 6.0 $\mathrm{m}^{2}$ each. Data on yield of various crops in sequences were recorded and converted to ton per hectare. The data of FP was recorded from adjacent farmers' plots.

Total system productivity was calculated as summation of individual (component) crop yield of each cropping cycle. The productivity of crop sequences was compared by calculating their economic rice equivalent yield (REY) using formula given by Ahlawat and Sharma (1993), where, 


$$
\mathrm{REY}=\frac{\text { Yield of each crop }\left(\mathrm{t} \mathrm{ha}^{-1}\right) \times \text { Economic value of respective crop }\left(\mathrm{Tk} \mathrm{t}^{-1}\right)}{\text { Price of rice grain }\left(\mathrm{Tk} \mathrm{t}^{-1}\right)}
$$

\section{Marginal benefit cost ratio (MBCR)}

The economic analysis was done following the method suggested by CIMMYT (1988). The MBCR can be computed as the marginal value product (MVP) over the marginal value cost (MVC). It can be computed as

$$
\text { MBCR }=\frac{\text { MVP }(\text { over control })}{\text { MVC }(\text { over control })}
$$

\section{Apparent nutrient balance}

Apparent nutrient balance was estimated considering the total amount of nutrient added to the soil through different sources and the total amount of nutrient uptake by the crop(s) (crops grain and their straw) each year. This calculation was valid particularly for $\mathrm{P}$ and $\mathrm{K}$ while calculating $\mathrm{N}$ balance, a $30 \% \mathrm{~N}$ loss have been assumed through different losses (like leaching, denitrification and volatilization loss etc). Apparent nutrient balance was expressed in $\mathrm{kg} \mathrm{ha}^{-1} \mathrm{yr}^{-}$ ${ }^{1}$. The mean annual apparent $\mathrm{N}$ balance for the total pattern was calculated using the following formula:

$$
X_{\mathrm{a}}=\left(\mathrm{X}_{\mathrm{f}}+\mathrm{X}_{\mathrm{r}}+\mathrm{X}_{\mathrm{i}}+\mathrm{X}_{\mathrm{b}}+\mathrm{X}_{\mathrm{cri}}\right)-\mathrm{X}_{\mathrm{rem}}
$$

\footnotetext{
Where

$\mathrm{Xa}=$ Apparent gain $(+)$ or loss (-) of $\mathrm{N}\left(\mathrm{kg} \mathrm{ha}^{-1}\right)$

$\mathrm{X}_{\mathrm{f}}=\mathrm{N}$ added through inorganic sources $\left(\mathrm{kg} \mathrm{ha}^{-1}\right)$

$\mathrm{Xr}=\mathrm{N}$ added through rainfall $\left(\mathrm{kg} \mathrm{ha}^{-1}\right)$

$\mathrm{Xi}=\mathrm{N}$ added through irrigation water $\left(\mathrm{kg} \mathrm{ha}^{-1}\right)$

$\mathrm{Xb}=\mathrm{N}$ added through $\mathrm{BNF}\left(\mathrm{kg} \mathrm{ha}^{-1}\right)$

$\mathrm{Xcri}=\mathrm{N}$ added through crop residue incorporation $\left(\mathrm{kg} \mathrm{ha}^{-1}\right)$

$\mathrm{Xrem}=\mathrm{N}$ removed by crops and loss through different systems $\left(\mathrm{kg} \mathrm{ha}^{-1}\right)$.

Apparent $\mathrm{N}$ balances were calculated from sequences.
}

The annual apparent $\mathrm{P}$ or $\mathrm{K}$ balance was calculated using the following simple equation:

$$
Y_{\mathrm{a}}=\left(\mathrm{Y}_{\mathrm{f}}+\mathrm{Y}_{\mathrm{r}}+\mathrm{Y}_{\mathrm{i}}+\mathrm{Y}_{\mathrm{cri}}\right)-\mathrm{Y}_{\text {rem }}
$$

Where

$\mathrm{Ya}=$ Apparent gain $(+)$ or loss (-) of nutrient $(\mathrm{P}$ or $\mathrm{K})\left(\mathrm{kg} \mathrm{ha}^{-1}\right)$

$\mathrm{Y}_{\mathrm{f}}=$ Nutrient $(\mathrm{P}$ or $\mathrm{K})$ added through inorganic sources $\left(\mathrm{kg} \mathrm{ha}^{-1}\right)$

$\mathrm{Yr}=$ Nutrient $(\mathrm{P}$ or $\mathrm{K})$ added through rainfall $\left(\mathrm{kg} \mathrm{ha}^{-1}\right)$

$\mathrm{Yi}=$ Nutrient $(\mathrm{P}$ or $\mathrm{K})$ added through irrigation water $\left(\mathrm{kg} \mathrm{ha}^{-1}\right)$

Ycri= Nutrient $(\mathrm{P}$ or $\mathrm{K})$ added through crop residue incorporation $\left(\mathrm{kg} \mathrm{ha}^{-1}\right)$

Yrem $=$ Nutrient $(\mathrm{P}$ or $\mathrm{K})$ removed by crops through different systems $\left(\mathrm{kg} \mathrm{ha}^{-1}\right)$.

Grain and straw samples of different crops were analyzed in the SRDI laboratory, Shyampur, Rajshahi determine the concentration of $\mathrm{N}, \mathrm{P}$ and $\mathrm{K}$. The data were analyzed statistically with open source software R (R Core Team, 2017).

Table1. Details of cultural practices adopted for different crops in field experiments 


\begin{tabular}{|c|c|c|c|c|c|c|c|c|c|c|c|}
\hline \multirow[t]{2}{*}{ Treat. } & \multirow[t]{2}{*}{ Crop } & \multirow[t]{2}{*}{$\begin{array}{r}\text { Seed rate } \\
\left(\mathrm{kg} \mathrm{ha}^{-1}\right)\end{array}$} & \multirow[t]{2}{*}{$\begin{array}{l}\text { Spacing } \\
(\mathrm{cm})\end{array}$} & \multirow{2}{*}{$\begin{array}{c}\text { Date of } \\
\text { Sowing / } \\
\text { planting }\end{array}$} & \multirow[t]{2}{*}{$\begin{array}{c}\text { Date of } \\
\text { Harvesting }\end{array}$} & \multicolumn{6}{|c|}{$\begin{array}{l}\text { Rate of fertilizer application } \\
\qquad\left(\mathrm{kg} \mathrm{ha}^{-1}\right)\end{array}$} \\
\hline & & & & & & $\mathrm{N}$ & $\mathrm{P}$ & $\mathrm{K}$ & $\mathrm{S}$ & $\mathrm{Zn}$ & $\mathrm{B}$ \\
\hline \multirow{4}{*}{$\begin{array}{l}\text { IP } \\
\text { (Improved } \\
\text { Pattern) }\end{array}$} & Lentil & 45 & Broad & 5-7 Nov. & 22-28 Feb. & 23 & 18 & 20 & - & - & 1.0 \\
\hline & Mungbean & 30 & Broadcast & $\begin{array}{c}1-5 \\
\text { March }\end{array}$ & 5-10 May & 20 & 15 & 16 & - & - & 1.0 \\
\hline & T.Aus & 40 & $20 \times 15$ & $\begin{array}{l}15-20 \\
\text { May }\end{array}$ & $\begin{array}{l}5-10 \\
\text { August }\end{array}$ & 80 & 15 & 30 & 12 & 2 & - \\
\hline & T.Aman & 40 & $20 \times 15$ & $\begin{array}{l}10-15 \\
\text { August }\end{array}$ & 1-5 Nov. & 80 & 15 & 30 & 12 & 2 & - \\
\hline \multirow{2}{*}{$\begin{array}{l}\text { FP } \\
\text { (Farmers } \\
\text { Practice) }\end{array}$} & Boro & 50 & $20 \times 15$ & $\begin{array}{l}25-30 \\
\text { January }\end{array}$ & 15-20 May & 100 & 15 & 30 & 10 & 2 & - \\
\hline & T.aman & 40 & $20 \times 15$ & $\begin{array}{c}15-20 \\
\text { July }\end{array}$ & 1-7 Nov. & 75 & 12 & 26 & 10 & - & - \\
\hline
\end{tabular}

Table 2. Chemical properties of soils (0-15 and 15-30 cm depth) of the experimental field after two cycle at FSRD site, Kadamshahar, Godagari

\begin{tabular}{|c|c|c|c|c|c|c|c|c|}
\hline \multirow{2}{*}{$\begin{array}{l}\text { Depth } \\
(\mathrm{cm})\end{array}$} & \multirow[t]{2}{*}{$\mathrm{pH}$} & \multirow{2}{*}{$\begin{array}{c}\text { Organic } \\
\text { matter }(\%)\end{array}$} & $\mathrm{K}$ & \multirow{2}{*}{$\begin{array}{c}\text { Total N } \\
(\%)\end{array}$} & $\mathrm{P}$ & $\mathrm{S}$ & $\mathrm{B}$ & $\mathrm{Zn}$ \\
\hline & & & meq /100g soil & & \multicolumn{4}{|c|}{ Micro gram/g soil } \\
\hline $0-15$ & 7.2 & 1.1 & 0.21 & 0.07 & 15.6 & 6.2 & 0.19 & 0.18 \\
\hline $15-30$ & 7.8 & 0.87 & 0.21 & 0.05 & 7.8 & 10.6 & 0.17 & 0.29 \\
\hline Mean & 7.50 & 0.98 & 0.21 & 0.06 & 11.70 & 8.40 & 0.18 & 0.23 \\
\hline & $\begin{array}{l}\text { Slightly } \\
\text { alkaline }\end{array}$ & Low & Medium & $\begin{array}{l}\text { Very } \\
\text { low }\end{array}$ & Low & Low & Low & $\begin{array}{l}\text { Very } \\
\text { low }\end{array}$ \\
\hline
\end{tabular}

\section{Results and discussion}

\section{Seed yield of mungbean}

In the late Rabi season, mungbean was cultivated in only the IP. In 2015-16, mungbean seed yield was found $650 \mathrm{~kg} \mathrm{ha}^{-1}$ and $720 \mathrm{~kg} \mathrm{ha}^{-1}$ 2016-17 (Table 3). Average over the years seed yield was $680 \mathrm{~kg} \mathrm{ha}^{-1}$ (Table 3). Mungbean was sown in early March for accommodating 4 crops in a year.

\section{Yield of T. Aus rice}

T. Aus rice was cultivated in the IP while FP remained fallow. The T. Aus yield was found higher 5.50 t ha-1 in 2015-16 than in 2016-17 (4.7 t ha-1) (Table 3). Average grain yield was $5.10 \mathrm{t} \mathrm{ha}^{-1}$ and straw yield was $6.47 \mathrm{tha}^{-1}$ (Table 3 ).

Table 3. Average yield $\left(\mathrm{t} \mathrm{ha}^{-1}\right)$ and REY $\left(\mathrm{t} \mathrm{ha}^{-1}\right)$ of different cropping pattern during 2015-16 and 2016-17

\begin{tabular}{|c|c|c|c|c|c|c|c|c|c|c|}
\hline \multirow[t]{3}{*}{$\mathrm{CP}$} & \multicolumn{8}{|c|}{ Average yield $\left(\mathrm{t} \mathrm{ha}^{-1}\right)$ during $2015-16$ and 2016-17 } & \multirow{3}{*}{$\begin{array}{c}\text { REY } \\
\left(\mathrm{t} \mathrm{ha}^{-1}\right)\end{array}$} & \multirow{3}{*}{$\begin{array}{c}\% \\
\text { increase } \\
\text { yield }\end{array}$} \\
\hline & \multicolumn{2}{|c|}{ Mungbean } & \multicolumn{2}{|c|}{ T. Aus } & \multicolumn{2}{|c|}{ T. Aman } & \multicolumn{2}{|c|}{ Lentil / Boro } & & \\
\hline & Grain & Straw & Grain & Straw & Grain & Straw & Grain & Straw & & \\
\hline IP & 0.68 & 1.45 & 5.1 & 6.47 & 3.37 & 5.21 & $\begin{array}{c}4.63 \\
(1.05)\end{array}$ & 1.15 & 15.01 & 46.29 \\
\hline FP & - & - & - & - & 4.8 & 6.1 & 5.46 & 6.66 & 10.26 & \\
\hline t-test & & & & & ** & $* *$ & $* *$ & $* *$ & $* *$ & \\
\hline
\end{tabular}

NB. Value in parenthesis indicating lentil yield; ** indicating significant in $1 \%$; Value in parenthesis indicating lentil yield ; Price of rice -Tk. $17 \mathrm{~kg}^{-1}$, Lentil-Tk. $75 \mathrm{~kg}^{-1}$ and Mungbean- Tk. $50 \mathrm{~kg}^{-1}$

\section{Grain yield of T. Aman rice}


Grain yield of T.Aman rice was found higher from FP (av. $\left.4.80 \mathrm{tha}^{-1}\right)$ in both years. In second year, yield of T. Aman rice was higher than first year (Table 4). This yield was mainly due to the variation in yield attributes. It was observed that the yield components (number of panicle hill $^{-1}$ and grains panicle ${ }^{-1}$ ) were higher in FP which ultimately increased grain yield compared to IP and straw yield of $6.10 \mathrm{t} \mathrm{ha}^{-1}$. The IP gave 3.37 and $5.21 \mathrm{t} \mathrm{ha}^{-1}$ grain and straw yield, respectively. The sterility percentage was higher which ultimately resulted to lower yield.

Table 4. Average $\mathrm{P}$ uptake $\left(\mathrm{kg} \mathrm{ha}^{-1} \mathrm{yr}^{-1}\right)$ by grain and straw of crops and system in response to cropping pattern in 2015-16 and 2016-17

\begin{tabular}{lcccccccccccc}
\hline CP & \multicolumn{2}{c}{ Mungbean } & \multicolumn{2}{c}{ T. Aus } & \multicolumn{2}{c}{ T. Aman } & \multicolumn{2}{c}{ Lentil / Boro } & \multicolumn{3}{c}{ System } \\
\cline { 2 - 13 } & Grain & Straw & Grain & Straw & Grain & Straw & Grain & Straw & Grain & Straw & Total \\
\hline IP & 3.74 & 7.97 & 15.3 & 8.41 & 18.53 & 6.77 & 3.15 & 2.65 & 40.72 & 25.8 & 66.52 \\
FP & - & - & - & - & 14.4 & 7.93 & 16.38 & 8.66 & 30.78 & 16.59 & 47.37 \\
\hline
\end{tabular}

\section{Rabi crops (Lentil and Boro)}

In Rabi season, lentil was cultivated in IP while Boro rice in FP. For comparison, the economic yield of lentil was converted to rice equivalent yield (REY). The two-year average REY tended to be lower $\left(4.63 \mathrm{t} \mathrm{ha}^{-1}\right)$ in IP than that of FP $\left(5.46 \mathrm{t} \mathrm{ha}^{-1}\right)$ (Table 3). In Barind area, lentil yield is low due clay type soil, drought etc.. Higher lentil yield was observed in $2^{\text {nd }}$ year than $1^{\text {st }}$ year (Table 3).

\section{Rice equivalent yield}

The IP recorded higher REY (15.01 t ha-1) than that of FP $\left(10.26 \mathrm{t} \mathrm{ha}^{-1}\right)$. Total productivity increased by $46.29 \%$ in IP over FP (Table 6). The IP took 345 days for its cycle while 215 days in FP (Table 3).Several scientists also reported that cropping sequences employing a summer grain legume produced significantly higher REY than the Rice-Rice sequence (Singh et al., 2011; Chauhan et al., 2012; Singh et al., 2014).

\section{Economic analysis}

Cropping pattern attributed a remarkable impact on variable cost, gross return, gross margin and marginal benefit cost ratio (MBCR) (Table 5). In general, four crop based pattern markedly enhanced the variable cost. From two years result showed that IP had higher cultivation cost (Tk. 1,30,750 ha ${ }^{-1}$ ) than FP (Tk. 96,600 ha-1). Annual cost of cultivation increased with increasing cropping intensity, with the triple or more-cropping system incurring considerable higher costs than the double-cropping system primarily due to cost of fertilizer, labour and plant protection (Biswas et al., 2006; Singh et al., 2011, Hossain et al., 2016b). IP had higher gross return (Tk. 2,65,500 ha-1) and gross margin (Tk. 1,34,750 ha-1) than FP. The MBCR was 1.38 in IP over FP. This was mainly due to the production potential accompanied with good monetary returns of components crops (lentil and T. Aus rice). On the other hand FP gave lower gross return (Tk.183990) and gross margin (Tk. 87390 ha $\left.^{-1}\right)$.

Table 5. Economic analysis as influenced by four crop-based cropping pattern in average of 2015-16 and 2016-17

\begin{tabular}{lccccc}
\hline CP & $\begin{array}{c}\text { Field duration } \\
\text { of crop } \\
\text { sequence (day) }\end{array}$ & $\begin{array}{c}\text { Gross return } \\
\left(\mathrm{Tk}_{\mathrm{h}} \mathrm{ha}^{-1}\right)\end{array}$ & $\begin{array}{c}\text { Cultivation } \\
\text { cost } \\
\left(\mathrm{Tk} . \mathrm{ha}^{-1}\right)\end{array}$ & $\begin{array}{c}\text { Gross margin } \\
\left(\mathrm{Tk}^{-1} \mathrm{ha}^{-1}\right)\end{array}$ & MBCR \\
\hline IP & 345 & 265500 & 130750 & 134750 & 1.38 \\
FP & 215 & 183990 & 96600 & 87390 & \\
\hline
\end{tabular}

\section{Input}


Urea: $16 \mathrm{Tk} \mathrm{kg}^{-1}$, TSP: $22 \mathrm{Tk} \mathrm{kg}^{-1}$, MoP: $15 \mathrm{Tk} \mathrm{kg}^{-1}$, gypsum: $6 \mathrm{Tk} \mathrm{kg}^{-1}$, zinc sulphate: $120 \mathrm{Tk}$ $\mathrm{kg}^{-1}$, boric acid: $150 \mathrm{Tk} \mathrm{kg}^{-1}$, rice seed: $35 \mathrm{Tk} \mathrm{kg} \mathrm{kg}^{-1}$, Mungbean seed : $60 \mathrm{Tk} \mathrm{kg}^{-1}$, Lentil seed: 90 Tk $\mathrm{kg}^{-1}$, powertiller (1 pass): $2250 \mathrm{Tk} \mathrm{ha}^{-1}$, irrigation (1 time): $900 \mathrm{Tk} \mathrm{ha}^{-1}$ and Labour: 200 Tk $\operatorname{day}^{-1}(8$ hours $)$

\section{Output}

Rice grain: $17.00 \mathrm{Tk} \mathrm{kg}^{-1}$, Lentil seed: $75 \mathrm{Tk} \mathrm{kg}^{-1}$, Mungbean grain: $50 \mathrm{Tk} \mathrm{kg}^{-1}$, ricestraw: 0.75 $\mathrm{Tk} \mathrm{kg}^{-1}$

\section{Changes in soil fertility}

There was no difference in the lower layer $(15-30 \mathrm{~cm}$ depth) between initial soil and that after two crop cycle. Minor change was observed in top soil $(0-15 \mathrm{~cm})$ after two crop cycle (Table1 and Table 2). After two years cycle, there was a very little change in soil $\mathrm{pH}$ compared to initial soil. The reduction in $\mathrm{pH}$ occurred possibly due to the production of organic acids from the decomposition of biomass of herbaceous legumes (mungbean and lentil). Decreases in $\mathrm{pH}$ have also been reported in other studies with cropping systems (Chadha et. al., 2009; Hossain et al., 2016a). Soil organic matter (SOM) in soil increased slightly due to legumes had been included. The inclusion of legumes as a residue retained in cropping sequences improves the SOM status (Ali, 2003). Similar to SOM the inclusion of legumes in IP improved soil N compared to the initial value. Furthermore, the mungbean biomass added was rich in $\mathrm{N}$, which might have accelerated nitrogen fixation by free-living organisms. Compared with the initial value, the available $\mathrm{P}$ content of soil increased. In contrast to $\mathrm{P}$, exchangeable $\mathrm{K}$ was depleted after two crop cycles, relative to initial soil. These results indicate that there was a higher uptake of $\mathrm{K}$ than the amount added, which may lead to a serious depletion of $\mathrm{K}$ in the long term. This result is supported by Panaullah et al. (2006). Similar to K, the available S decreased. Available Zn and $\mathrm{B}$ content showed an increasing trend after the two crop cycles.

\section{Nutrient Uptake and Apparent Balance}

\section{Nitrogen uptake and apparent balance}

Mungbean was grown in IP, $\mathrm{N}$ uptake by mungbean grain $\left(21.42 \mathrm{~kg} \mathrm{ha}^{-1}\right)$ and stover $(23.20 \mathrm{~kg}$ $\mathrm{ha}^{-1}$ ) was almost similar though concentration of $\mathrm{N}$ is higher in grain than that of mungbean stover (Table 5). Lower seed yield of mungbean resulted to lower $\mathrm{N}$ uptake by mungbean grain. In IP, $\mathrm{N}$ uptake by T. Aus grain and straw was 68.85 and $44.0 \mathrm{~kg} \mathrm{ha}^{-1}$, respectively. Nitrogen uptake by T. Aman in IP is lower than that of FP. Farmers normally grow long duration Swarna variety. It produced higher yield resulted to higher $\mathrm{N}$ uptake. $\mathrm{N}$ uptake by grain in both Aman rice varieties is higher than that of straw. In lentil, about $70 \%$ of total $\mathrm{N}$ uptake was recorded by lentil grain. However, average $\mathrm{N}$ uptake by lentil grain and straw was 36.12 and $13.80 \mathrm{~kg} \mathrm{ha}^{-1}$, respectively. Boro rice var. BRRI dhan 28 in FP removed substantial amount of $\mathrm{N}$ where higher amount by grain $\left(73.71 \mathrm{~kg} \mathrm{ha}^{-1}\right)$ than that straw (45.29 $\left.\mathrm{kg} \mathrm{ha}^{-1}\right)$. Cropping pattern had an effect on system level grain, straw and total $\mathrm{N}$ uptake (Table 5). In system level, relatively higher amount of $\mathrm{N}$ was removed by grain in both the cropping patterns. The IP, which included four crops recorded more $\mathrm{N}$ uptake by grain and straw than those of FP. The IP $\left(288.31 \mathrm{~kg} \mathrm{ha}^{-1}\right)$ showed the higher system level total $\mathrm{N}$ uptake than FP $\left(225.28 \mathrm{~kg} \mathrm{ha}^{-1}\right)$ due to higher total biomass production.

Table 6. Average $\mathrm{N}$ uptake $\left(\mathrm{kg} \mathrm{ha}^{-1} \mathrm{yr}^{-1}\right)$ by grain and straw of crops and system in response to cropping pattern in 2015-16 and 2016-17

\begin{tabular}{cccccccccccc}
\hline CP & \multicolumn{2}{c}{ Mungbean } & \multicolumn{2}{c}{ T. Aus } & \multicolumn{2}{c}{ T. Aman } & \multicolumn{2}{c}{ Lentil / Boro } & \multicolumn{3}{c}{ System } \\
\cline { 2 - 12 } & Grain & Straw & Grain & Straw & Grain & Straw & Grain & Straw & Grain & Straw & Total \\
\hline IP & 21.42 & 23.2 & 68.85 & 44.0 & 45.49 & 35.43 & 36.12 & 13.8 & 171.88 & 116.43 & 288.31
\end{tabular}


Apparent $\mathrm{N}$ balance was calculated as the difference between $\mathrm{N}$ inputs and $\mathrm{N}$ outputs. Apparent $\mathrm{N}$ balance indicates that $\mathrm{N}$ variations were related primarily to applied $\mathrm{N}$ from different sources, crop $\mathrm{N}$ uptake and $\mathrm{N}$ losses. Annual system-level $\mathrm{N}$ input for IP (Lentil-Mungbean -T.Aus-T. Aman rice) was greater than FP (Boro-Fallow-T.Aman) (Fig. 1). Apparent N losses increased substantially with IP, demonstrating that $\mathrm{N}$ losses were proportional to the rate of fertilizer $\mathrm{N}$. Considering BNF and $\mathrm{N}$ losses, the IP had a negative $\mathrm{N}$ balance, which was $-10.72 \mathrm{~kg} \mathrm{ha}^{-1}$. However, FP showed more negative balance $\left(-35.96 \mathrm{~kg} \mathrm{ha}^{-1}\right)$ than IP.

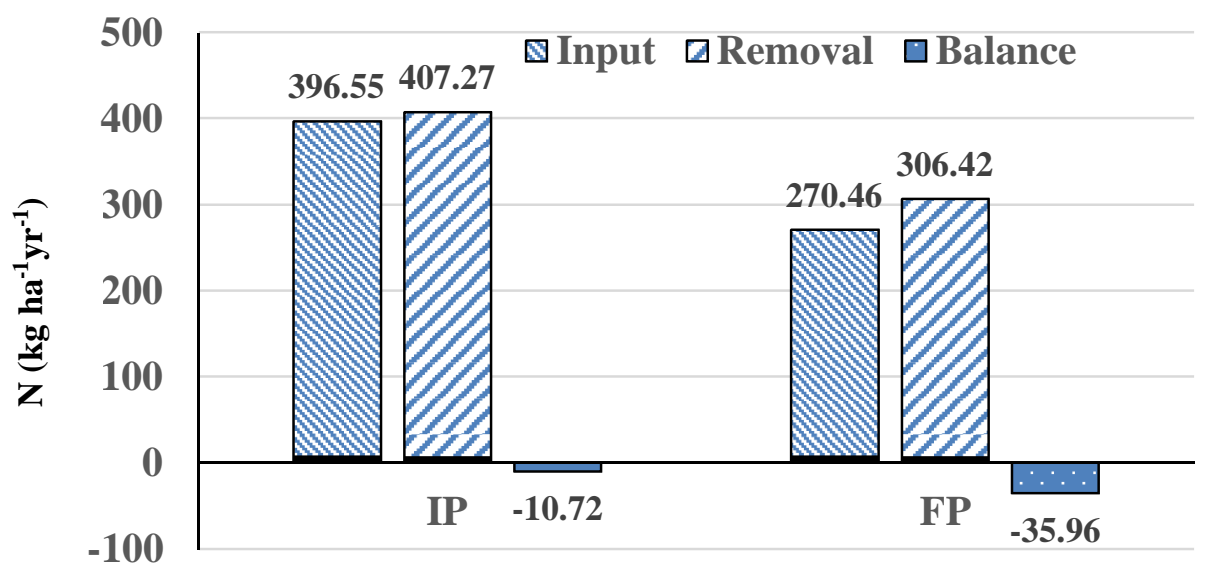

Fig. 1. Average inputs, outputs and balance of $\mathrm{N}$ in response to cropping pattern in 2015-16 and 2016-17

\section{Phosphorus uptake and apparent balance}

Generally $\mathrm{P}$ uptake is low by plant in compared to $\mathrm{N}$ and $\mathrm{K}$. Again, rice crop removed more $\mathrm{P}$ than legume crops. In IP, P uptake by mungbean grain was $\left(3.74 \mathrm{~kg} \mathrm{ha}^{-1}\right)$ and stover $\left(7.97 \mathrm{~kg} \mathrm{ha}^{-}\right.$ ${ }^{1}$ ) (Table 6). In IP, P uptake by T. Aus grain and straw was 15.30 and $8.41 \mathrm{~kg} \mathrm{ha}^{-1}$, respectively. $\mathrm{P}$ uptake by T. Aman grain was higher in FP $\left(18.53 \mathrm{~kg} \mathrm{ha}^{-1}\right)$ and lower in IP $\left(14.4 \mathrm{~kg} \mathrm{ha}^{-1}\right)$. Similar trend was observed for $\mathrm{P}$ uptake by $\mathrm{T}$. Aman rice straw. These results indicating that $\mathrm{P}$ uptake by crops resembled with those of crop yields. The $\mathrm{P}$ uptake was almost equal for grain (3.15 $\left.\mathrm{kg} \mathrm{ha}^{-1}\right)$ and straw $\left(2.65 \mathrm{~kg} \mathrm{ha}^{-1}\right)$ in lentil. The $\mathrm{P}$ uptake by Boro rice grain $\left(16.38 \mathrm{~kg} \mathrm{ha}^{-1}\right)$ was found higher than Boro rice straw $\left(8.66 \mathrm{~kg} \mathrm{ha}^{-1}\right)$.In system level, total $\mathrm{P}$ uptake was greater in IP $\left(66.52 \mathrm{~kg} \mathrm{ha}^{-1}\right)$ than FP $\left(47.37 \mathrm{~kg} \mathrm{ha}^{-1}\right)$. 


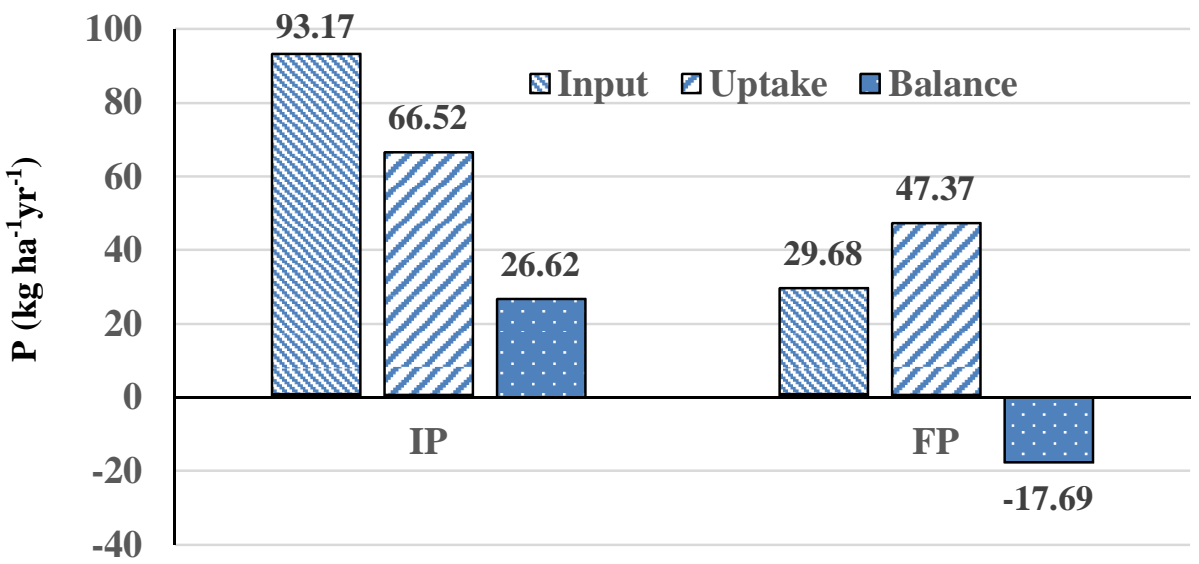

Fig. 2. Average inputs, outputs and balance of $P$ in response to cropping pattern in 2015-16 and 2016-17

System-level total P input was lower in FP and higher in IP, because the later pattern received more $\mathrm{P}$ through fertilizer and crop residue incorporation (Fig. 2). The FP showed negative $\mathrm{P}$ balance $\left(-17.69 \mathrm{~kg} \mathrm{ha}^{-1}\right)$ indicating $\mathrm{P}$ doses were insufficient to maintain the crop productivity for long run. However, the pattern IP got a positive balance, which was $26.65 \mathrm{~kg} \mathrm{ha}^{-1}$. Rijpma and Jahiruddin (2004) also reported that the nutrient balance for $\mathrm{P}$ is slightly negative in Bangladesh soils

\section{Potassium uptake and apparent balance}

$\mathrm{K}$ uptake by mungbean grain $\left(10.4 \mathrm{~kg} \mathrm{ha}^{-1}\right)$ was found lower than that of mungbean stover (31.17 $\mathrm{kg} \mathrm{ha}^{-1}$ ) which is only grown in IP (Table 7). In IP, K uptake by T. Aus grain and straw were 15.81 and $110.0 \mathrm{~kg} \mathrm{ha}^{-1}$, respectively. $\mathrm{K}$ uptake by T. Aman straw was higher $(103.7 \mathrm{~kg} \mathrm{ha}$ ${ }^{1}$ ) in FP and lower (88.57 $\left.\mathrm{kg} \mathrm{ha}^{-1}\right)$ in IP. In case of T.Aman grain $\mathrm{K}$ uptake was found also higher in FP (14.88 $\left.\mathrm{kg} \mathrm{ha}^{-1}\right)$ and lower in IP $\left(10.45 \mathrm{~kg} \mathrm{ha}^{-1}\right)$. Long duration T. Aman rice variety accumulated higher amount of K.K uptake was recorded similar in grain $\left(11.55 \mathrm{~kg} \mathrm{ha}^{-1}\right)$ and straw (12.54 $\left.\mathrm{kg} \mathrm{ha}^{-1}\right)$ in lentil. $\mathrm{K}$ uptake by Boro rice straw was found much higher $(113.22 \mathrm{~kg}$ $\mathrm{ha}^{-1}$ ) than Boro rice grain $\left(16.93 \mathrm{~kg} \mathrm{ha}^{-1}\right)$.The IP removed more $\mathrm{K}$ than FP. About $85 \%$ of $\mathrm{K}$ was removed by straw. System-level input K was lower in FP and higher in IP. Apparent annual balance of $\mathrm{K}$ differed due to cropping patterns (Fig. 3). The balance was consistently negative being higher in FP (-170.90 kg ha-1) and lower in IP (-121.68 kg ha-1) sequence. These results are comparable with Singh et al., 2004; Panaullah et al., 2006). 


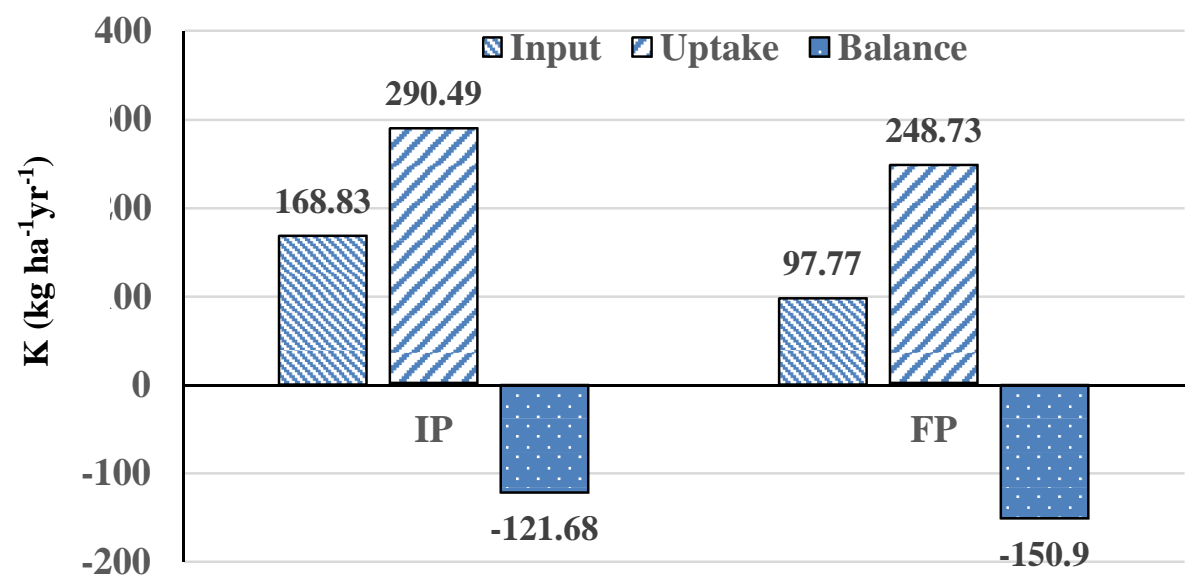

Fig. 3. Average inputs, outputs and balance of $\mathrm{K}$ in response to cropping pattern in 2015-16 and 2016-17

Table 7. Average $\mathrm{K}$ uptake $\left(\mathrm{kg} \mathrm{ha}^{-1} \mathrm{yr}^{-1}\right)$ by grain and straw of crops and system in response to cropping pattern in 2015-16 and 2016-17

\begin{tabular}{lccccccccccc}
\hline CP & \multicolumn{2}{c}{ Mungbean } & \multicolumn{2}{c}{ T. Aus } & \multicolumn{2}{c}{ T. Aman } & \multicolumn{2}{c}{ Lentil/Boro } & \multicolumn{3}{c}{ System } \\
\cline { 2 - 12 } & Grain & Straw & Grain & Straw & Grain & Straw & Grain & Straw & Grain & Straw & Total \\
\hline IP & 10.4 & 31.17 & 15.81 & 110.0 & 10.45 & 88.57 & 11.55 & 12.54 & 48.21 & 242.28 & 290.49 \\
FP & - & - & - & - & 14.88 & 103.7 & 16.93 & 113.22 & 31.81 & 216.92 & 248.73 \\
\hline
\end{tabular}

Note: IP =Mungbean- T. Aus -T. Aman rice-Lentil; FP =Boro rice-Fallow-T. Aman rice

\section{Conclusion}

The results of the study indicated that existing cropping pattern, Boro - Fallow-T. Aman could be improved with four crops pattern such as Lentil-Mungbean -T.Aus-T.Aman rice in the High Barind Tract of Bangladesh. The improved pattern, Lentil - Mungbean -T.Aus-T.Aman rice is superior and viable over the existing pattern, Boro - Fallow-T. Aman rice cropping pattern in respect of system productivity, profitability and soil fertility.

\section{References}

Ahlawat, I. P. S., Sharma, R. P. 1993. Agronomid terminology. 3rd edition. New Delhi: Indian Soci. Agron.

Ali, M. 2003. Role of legumes in cropping systems in the Indo-gangetic plains of India. In: Addressing Resource Conservation Issues in Rice-Wheat Systems of South Asia. RiceWheat Consortium for the Indo-Gangetic Plains, CIMMYT. NASC Complex, New Delhi110012, India. pp. 210-214.

BARC (Bangladesh Agricultural Research Council) 2012: Fertilizer Recommendation Guide. BARC, Farmgate, Dhaka 1215, Bangladesh.

BBS (Bangladesh Bureau of Statitics) 2016. Statistical Yearbook of Bangladesh ( $31^{\text {st }}$ edition), BBS, Statistics \&Informatic Division, Ministry of Planning, Government of the People's Republic of Bangladesh, Dhaka, Bangladesh. 
Biswas, B., D.C. Ghosh,M. K.Dasgupta, N. Trivedi, J. Timsina andA.Dobermann. 2006. Integrated assessment of cropping systems in the Eastern Indo-Gangetic plain. Field Crops Res. 99:35-47.

Chadha, M.L., T. S. Bains, H.S. Sekhon and S.K. Sain. 2009. Short duration mungbean for diversification of rice-wheat system. Milestones in food legume research II- The Peninsular Region. Kanpur, 151-177.

CIMMYT (International Maize and Wheat Improvement Center). 1988. From Agronomic Data to Farmer Recommendations: An Economic Training Manual. CIMMYT, Mexico, D. F. 79 p.

Hossain, M.S., A. Hossain,M.A. R.Sarkar, M.Jahiruddin, J. A. Teixeira da Silva, M. Israil Hossai,. 2016a. Productivity and soil fertility of the rice-wheat system in the high Ganges River floodplain of Bangladesh is influenced by the inclusion of legumes and manure. Agric. Ecosyst. Environ. 218, 40-52. doi:http://dx.doi.org/ 10.1016/j.agee.2015.11.017.

Hossain, M.S., M. A. R. Sarkar, M. Jahiruddin, A.K Chaki and A. M. Khan. 2016b. Productivity and partial budget analysis in wheat-rice sequences as influenced by integrated plant nutrition system and legume crops inclusion. Bangladesh J. Agril. Res. 41(1): 17-39

Konrad, M., E.Kirkby,H. Kosengartenand T. Appel. 2001. Principles of plant nutrition (5thed.). Kluwer Academic Publishers. ISBN 1-4020-0008-1.

Panaullah, G. M., J. Timsina, M. A. Saleque, M. Ishaque, A. B. M. B. U. Pathan, D. J. Connor, P. K.Saha, M. A. Quayyum, E. Humphreys and C. A. Meisner.2006. Nutrient Uptake and Apparent Balances for Rice-Wheat Sequences. III. Potassium. J. Plant Nutr. 29: 173-187.

Rijpma, J. and M. Jahiruddin. 2004. National strategy and plan for use of soil nutrient balance in Bangladesh. A consultancy report, SFFP, Khamarbari, Dhaka, 7-26

Singh, R.K., J. S.Bohra, T.Nath, Y. Singhand K. Singh. 2011. Integrated assessment of diversification of rice-wheat cropping system in Indo-Gangetic plain. Arch. Agron. Soil Sci. 57 (5):489-506.

Tirol-Padre, A., J. K.Ladha, A. P.Regmi, A. L.Bhandari and K.Inubushi.2007. Organic amendment affect soil parameters in two longterm rice-wheat experiments. Soil Sci. Soc. America J. 71: 442-52.

Worldometers. 2017. Elaboration of data by United Nations, Department of Economic and Social Affairs, Population Division. World Population Prospects: The 2017 Revision. (Mediumfertility variant). (www.Worldometers.info on 5 October 2017).

Yu, Y. L., L. HXue and L. Z Yang. 2014. Winter legumes in rice crop rotations reduces nitrogen loss, and improves rice yield and soil nitrogen supply. Agron. Sustain Dev. 34:633-40. 